\title{
Residents' perceptions of the environmental and social impacts of KCM's mining activities inNchangaNorth Township, Chingola, Zambia
}

\author{
Caroline Lusonde \\ Department of Geography and Environmental Studies \\ University of Zambia, P.O Box 32379, Lusaka, Zambia
}

Kabwe Harnadih Mubanga

Department of Geography and Environmental Studies

University of Zambia, P.O Box 32379, Lusaka, Zambia

Received: July 4, 2019 Accepted: July 26, 2019 Published: October 8, 2019

doi:10.5296/emsd.v8i4.15591～URL: https://doi.org/10.5296/emsd.v8i4.15591

\begin{abstract}
The study explores and assesses mining and its environmental and social impacts on communities within which mining activities take place. The focus is on a mining community in Chingola, Zambia called Nchanga North Township where mining is carried out by a mining group called Vedanta Resources Plc, KCM. The study investigates the real and latent environmental and social impacts and the residents' perception of impacts of mining activities on their communities in the light of the numerous promises and prospects that mining is said to provide for communities.
\end{abstract}

Nchanga North Township in Chingola was purposively selected as the study area because of its close proximity to KCM's Nchanga Mine. Several data collection methods were used, including; observations, literature review, 60 semi-structured interviews, water and soil sample analysis for $\mathrm{pH}$. In assessing the perceptions of residents towards the environmental and social impacts of mining activities, systematic random sampling was used to interview a total of 60 households. This was out of a total number of 540 households in Nchanga North Township.

It was found that mining operations at Nchanga mine were releasing dust to air mainly during blasting. There was also noise produced mainly by mine equipment and blasting operations. 
It was also discovered that suspended solids resulting from carry overs of sediments with runoff from pit slopes resulted into water contamination. There was no significant difference between the $\mathrm{pH}$ values measured at the eight sample points in Nchanga North Township (mean $=6.20 ;$ range $=5.07-8.14)$ and the expected normal soil $\mathrm{pH}($ mean $=6.25 ; \mathrm{t}=-0.121 ; \mathrm{p}=0.907)$ at probability level $\mathrm{p}=0.05$. This implies that there was no $\mathrm{pH}$ raising or decreasing contaminants in the soil. There was no significant difference between the water $\mathrm{pH}$ values obtained in the field with the normal water $\mathrm{pH}(\mathrm{t}=6.636 ; \mathrm{p}=0.095)$ at probability level $\mathrm{p}=$ 0.05. This implies that there was no $\mathrm{pH}$ raising or decreasing contaminants in the Kafue River at the point of sample collection. Nchanga North Township residents believe that mining operations at Nchanga mine are affecting their environment and social life negatively. The lack of an environmental management plan by the mine to combat the adverse effects on the residents meant the residents close to the mine, were highly affected negatively.

Keywords: Social impact assessment, Mining, Overburden, Tailings, Chingola, KCM

\section{Introduction}

The mining industry has been Zambia's economic backbone since independence. The industry generates $85 \%$ of the country's foreign exchange and contributes $30 \%$ to government revenues (Mwitwa and Kabemba2007). It is also responsible for 15\% of the national gross domestic product (GDP) (Feeney; 2001). About 15\% of Zambia's total workforce is employed in the mining industry (Mwitwa and Kabemba 2007). Even though the mining sector has made such contributions to Zambia's economy, it has increasingly come under pressure as regards to impacts on the environment.

Environmental pollution from mining is one of the major challenges that the modern world is facing (Anon 2006). According to Anon (2006), the production of one tonne of copper generates 110 tonnes of waste ore and 200 tonnes of overburden waste. He reported that the copper industry generated 3,348 million tonnes of waste material to produce 10.8 million tonnes of copper metal in 2004. The industry generated 16,709 million tonnes of waste material between 2000 and 2004 (Anon 2006).

A study by Naicker et al. (2003) in Johannesburg, South Africa, revealed that groundwater in mining districts were heavily contaminated and acidified as a result of oxidation of arsenic, barite, calcite, cyanide, fluorite, mercury, pyrite and quartz contained in the mine tailings dumps, and elevates concentrations of heavy metals in groundwater. Where the groundwater table was close to the surface, the upper soil profiles were severely contaminated by heavy metals due to capillary rise and evaporation of the groundwater. The polluted groundwater discharges into streams and contributes to stream flow, causing an increase in the acidity of stream water. The effect of the contaminated water from the mines can persist for more than $10 \mathrm{~km}$ beyond the source (Naicker et al., 2003).

Waste rock, tailings and other solid waste are the largest industrial solid waste generated by the mining industry (Feeney 2001). These wastes are mostly generated during the processes of extraction, beneficiation and processing of minerals, (Feeney 2001). Extraction is the first phase of resource mining and consists of initial removal of ore from the earth's crust. This is 
done by the process of blasting which results in generation of large volume of waste such as soil, debris and other material (Feeney 2001). Since mining involves large scale extraction, the volume of waste generated is equally large giving rise to environmental pollution concerns (Anon 2006; Das and Choudhury 2013).Mineral beneficiation is a process by which valuable constituents of an ore are concentrated by means of physical separation process (Das and Choudhury 2013). The main purpose of mineral beneficiation is to prepare the ore prior to downstream purification processes (Das and Choudhury 2013). Mineral processing is another stage of mining which generates solid waste, it occurs during the solid mineral extractive process and its goal is to produce granular material which meets a specific set of requirements in terms of material composition and physical characteristics (especially granulation) (Das and Choudhury 2013). During mineral processing, ores undergo ore dressing. Ore dressing is a process of mechanically separating the grains of ore minerals from the gangue minerals, to produce a concentrate containing most of the ore minerals; this process generates tailings containing the bulk of the gangue minerals (Das and Choudhury 2013).

There are two types of mining methods; opencast and underground mining. Opencast mining is the extraction of minerals or energy resources by operations exclusively involving personnel working on the surface without provision of manned underground operations (Das and Choudhury 2013). Underground mining is the method in which extraction of minerals is done beneath the surface of the earth. Since mining operations are conducted on the surface, opencast mining is more pollution prone and generates 8 to 10 times more quantities of waste compared to underground mining (Feeney 2001). Mine waste can be categorized into; tailings, overburden, waste rock, mine water, and other solid wastes.

Mining operations generate two types of waste rock - overburden and mine development rock. Overburden results from the development of surface mines, while mine development rock is a by-product of mineral extraction in underground mines (Anon 2006). The quantity and composition of waste rock varies greatly from site to site, but these wastes essentially contain the minerals associated with both the ore and host rock (Anon 1998). During the process of concentration, which involves grinding and milling, tailings are generated which are in a form of slurry, which contains certain hazardous contents such as arsenic, barite, calcite, cyanide, fluorite, mercury, pyrite and quartz. Tailings consist of ground rock and effluents that are generated in a mine processing plant; they are unrecoverable and uneconomic metals, minerals, chemicals, organics and process water; (Anon 1985). Many minerals cannot be used for metal extraction directly as the concentration of the basic ore is less and has to be concentrated before it can be used; (Das and Choudhury 2013). The characteristic of tailings depends on the type of ore and hence varies from mineral to mineral (Anon 2006). The slurry or the tailings are stored in a storage area commonly known as a Tailings Dam or a Tailings Management Facility (TMF) or Tailings Storage Facility (TSF).

Though most mining wastes such as over-burden are inert solid materials, the industry also generates toxic waste. Some of these toxins are inherently present in the ore, for example, heavy metals such as mercury, arsenic, lead, zinc and cadmium. These heavy metals leach out of stored waste piles, contaminating the local environment (Feeney 2001). The disposal of 
these mine wastes is critical to environmental quality maintenance.

A major environmental challenge relating to mining in many parts of the world is uncontrolled discharge of contaminated water (or decant) from mines (Banks et al., 1997; Pulles et al., 2005). KCM's mining activities in Zambia have resulted in similar challenges contributing to negative impacts on surrounding communities and on the environment. The Environmental Council of Zambia (2000) reported that wastewater discharged over the years from the mines have resulted in the accumulation of copper in the water and sediments. Furthermore, a study by Von der Heyden and New (2003) revealed that the concentrations of copper in the Kafue River sediments exceeded that found in other polluted river sediments worldwide. One of the ecological consequences of this is reduced fish stocks in the river, and since the Kafue River is a major fishery which supports thousands of household livelihoods, reduced fish stocks would adversely impacts these households (Chansa2006).

The Muntimpa stream is a source of drinking and domestic water for the local population. The stream flows into Mwambashi stream which subsequently discharges into Kafue River. The Kafue River has economic and social significance to many households inhabiting its catchment. It is a source of $40 \%$ of drinking water for the cities like, Lusaka, Kafue, Kitwe, and Chingola with about 50\% of the population living in the catchment (Ngulube et al. 2016). It is from the Kafue River that Mulonga Water and Sewerage Company (MWSC) extracts water to supply to the local people in Chingola. Some of this water is used for crop irrigation and urban agriculture besides domestic consumption. Considering the vital uses of this water for households, this study will assess the perceptions of residents on the possible impacts of disposal of mine waste on the surrounding communities.

Mining by its nature requires large tracts of land which has resulted in the displacement of surrounding communities in order to accommodate the mining operations. According to Oxfam Communique (1998), about 44,556 people who were living on mine land in Nchanga, Nkana, Mufulira, Luanshya, and Konkola were displaced in order to give way to mining operations in 1997. Mining activities can contribute to the physical disturbances to the landscape, creating eyesores such as waste rock piles and open pits, such activities may disturb the general ecology of an area. The disturbed ecology may not be replenished or may fail to regenerate even after mining ceases (Rhett, 2006).

Hence, the aim of the study was to investigate the perceptions of the locals living around $\mathrm{KCM}$ as regards to the environmental and social impacts of mining activities on the local people.

\section{Methodology}

\subsection{Overview of the Study Area}

The study was conducted in Nchanga Township which is located within ChingolaDistrict, on the Copperbelt Province of Zambia. The District lies approximately 450 kilometres NorthWest of Lusaka, the capital city of Zambia and 51 kilometres West of Kitwe. It shares the border with Chililabombwe in the North, Lufwanyama in the South-West, Mufulira in the East, Kalulushi in the South East and Solwezi in the North- West. It lies on the latitude of 


\section{Macrothink}

$12^{0} 30^{\prime} \mathrm{S}$ and longitude $27^{\circ} 50^{\prime} \mathrm{E}$ and at an altitude of $1300 \mathrm{~m}$ (CSO 2003). Nchanga Township shares its northern boundary with KCM owned Nchanga mine and is situated within a radius of $3 \mathrm{~km}$ from the Nchanga mine (CSO 2012).According to CSO(2010), Chingola has a population of 216,626. Nchanga TownshipwithinChingola has a population of 14,263, with $51.5 \%$ males and $48.5 \%$ females. Thetownship has 2139 households of which 984 households are in Nchanga South and 1155 are in Nchanga North (CSO, 2012). The total area of Chingola is $1,678 \mathrm{~km}^{2}$ and has a population density of 129.1 persons per square kilometre. The population growth rate for the town is $2.3 \%$ (CSO, 2012).

\subsection{State of the Mine}

KonkolaCopper Mines $(\mathrm{KCM})$ is a subsidiary of a mining group called Vedanta Resources Plc. (KCM 2002). KCM owns and operates Nchanga, Konkola, Nkana and Nampundwe mine sites in Zambia (Figure 1).

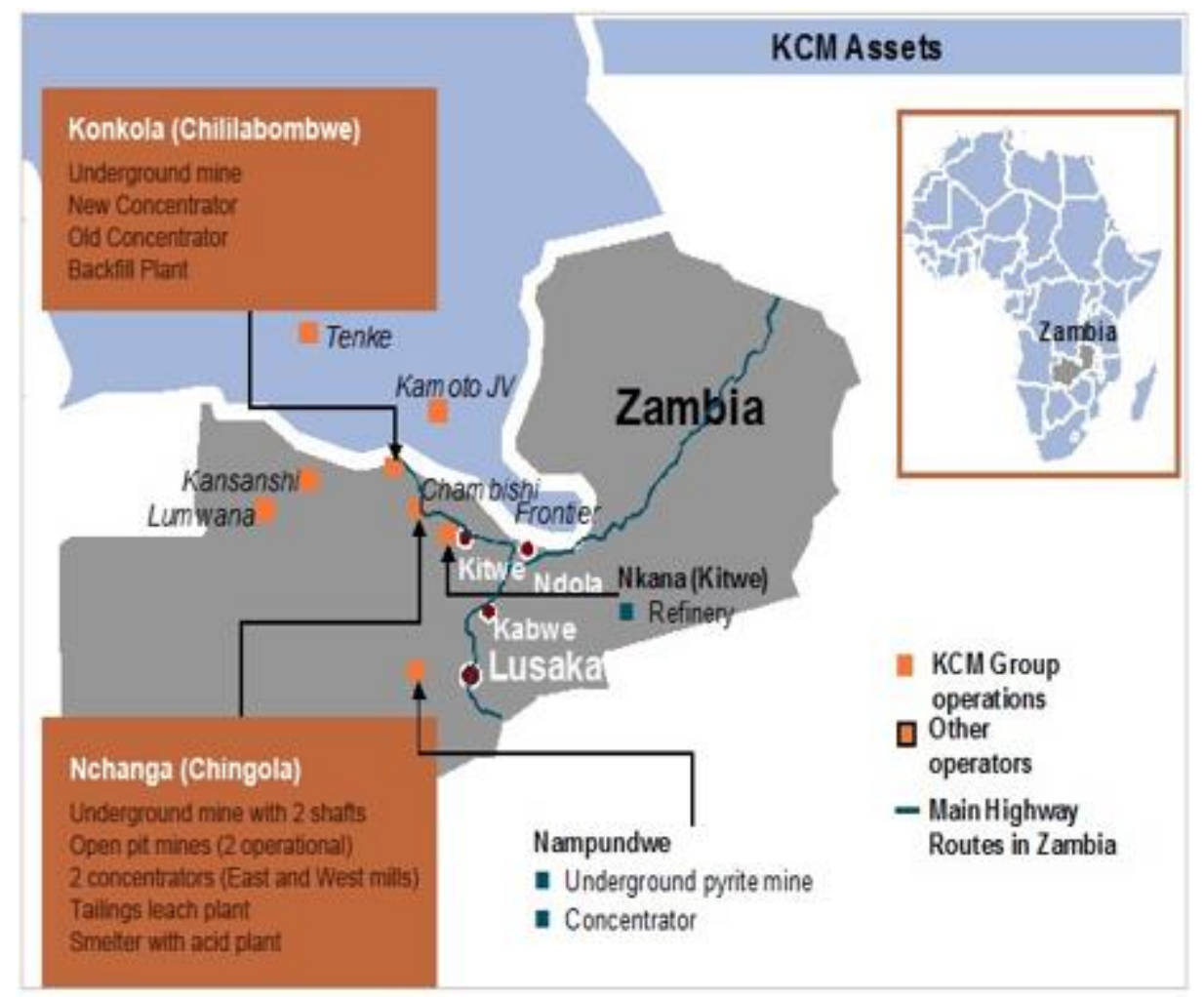

Figure 1. KCM owned minesin Zambia (Source: KCM, 2015)

Nampundwe mine is located in Lusaka Province, Nkana is situated in Kitwe, Konkola is located in Chililabombwe and Nchanga is in Chingola (Lungu, 2004). At its Nchanga mine site in Chingola (Figure 2), KCM undertakes both underground and open cast mining operations. In 2008, KCM commissioned the Nchanga copper smelter at Nchanga Mine to smelt copper concentrates from its own concentrates and purchased concentrates. Nchanga Open Pit mine (NOP) is the main open pit facility at Nchanga Mine and is situated $11 \mathrm{~km}$ from Chingola Central Business District. NOP mine covers an area of approximately $30 \mathrm{~km}^{2}$. 
It is the second largest open cast mine in the world (KCM 2015). The deepest part of the pit is $400 \mathrm{~m}$ below the surface. The mine accounts for approximately $45 \%$ of the total copper production at Nchanga Mine. Over the last decade, its annual production has averaged 93,000 tonnes of contained copper (KCM 2015). Currently, there are three distinct ore bodies from which mining is taking place, namely; the lower ore body (LOB), Block ' $A$ ' and Chingola ' $B$ '. These contribute $63 \%, 35 \%$ and $8 \%$ copper ore production, respectively (KCM; 2015).

\subsection{Sampling}

Selection of respondents for participation in the study was done using systematic random sampling (with a sampling unit of 9) of which a total of 60 households were selected. This was out of a total number of 540 households in Nchanga North Township. The head of the household was targeted for interviews but in cases where the head of the household was not around, the spouse was interviewed and in cases where both were around, both were interviewed.

\subsubsection{Sampling for Key Informants}

The selection of key informants was purposively done. This approach ensured that only those with knowledge of particular issues were interviewed. A total of four key informant interviews were conducted with experts from theChingola District Health Board (CDHB), Nchanga Mine, Chingola Municipal Council (C.M.C), and Mulonga Water and Sewerage Company. Data on management of mine wastes and methods of mine waste disposal was collected from Nchanga mine and Chingola Municipal council, and data on the state of water pollution in Nchanga North Township was collected from Mulonga and Water and Sewerage Company as the company that supplies water in Chingola.

\subsubsection{Semi- Structured Interviews}

A total of 60semi-structured interviews were administered to households in Nchanga North. This form of interviews was preferred as it was easier to elicit information from residents about how the activities of the mining company have impacted on them and their environment. The rationale for using semi-structured interviews stems from the fact that it helps to get in-depth information about the social and environmental impacts on the people on a one-on-one basis. In semi-structured interviews, the researcher was able to probe for information in cases where responses were not satisfactory (Bryman, 2008: 438).

\subsubsection{Observations}

The researcher used observations to confirm what respondents were saying about high levels of dust in the air due to blasting, noise due to blasting and mining machines. The researcher also observed the appearance and state of the buildings (houses) as residents were complaining of cracks on their houses due to blasting, and suspended solids in the water.

\subsubsection{Desk Research}

Reviewing literature on mining activities and its impact was very useful in broadening the general understanding of the nature and extent to which mining can impact on communities. 


\section{Macrothink}

For this research, documents on the operational activities of Nchanga mine, Corporate Social Responsibility and Environmental Impact Assessment as well as Impact Mitigation and Management Measures in mining communities were reviewed for further understanding.

\subsubsection{Data Analysis}

Descriptive statistics were used to analyze quantitative data. All statistical operations in this study were done with the help of Microsoft Excel 2010 (Microsoft Corporation, 2010) and SPS. Qualitative analysis of information from the semi-structured interviews with the key informants and Nchanga North residents was analyzed by summarizing the data into key themes, and recounting some experiences. This type of qualitative data analysis is called thematic analysis (Braun and Clarke, 2006).The emerging themes in these classes portrayed the prevailing perceptions of the majority of respondents who in this case were the Nchanga North residents.

\section{Results and Discussion}

\subsection{Demographic Characteristics of Respondents}

The study comprised of sixty (60) respondents of whom $38.3 \%$ were women and $61.7 \%$ were men. The gender imbalance was in no way based on any biased assumptions about gender equalities or inequalities because most of the households in Nchanga North were male headed. The household heads were respected and allowed to respond to issues concerning the households or community. At least $45 \%$ of the sampled respondents have lived in in Nchanga North Township between 2 and 10 years, $32 \%$ of the respondents have lived in the study area between 10 and 20 years while $16 \%$ have lived in the study area for more than 20 years and only $7 \%$ of the respondents have lived in the study area for less than a year.Of the 60 sampled, $20 \%$ were below 30 years old, $43.3 \%$ were between the ages of 31 and 40 years, $23.3 \%$ were between 41 and 50 years and 13.4\% were above 51 years old.Nchanga North Township had $10 \%$ of residents who had not attended formal education, $16.7 \%$ who had only attended school up to primary level, $41.7 \%$ of respondents have attended school up to secondary level and $31.6 \%$ have attended school up to tertiary level.

\subsection{Methods of Mine Waste Disposal Practiced at Nchanga Mine}

Categories of waste generated from KCM included tailings, overburden, waste rock and mine waste water (Table 1). Tailings dams are earth-fill embankment dams used to store by-products (tailings) of mining operations after separating the ore from gangue. Tailings can be solid, liquid or slurry of fine particles. 
Table 1. Methods of waste disposal at Nchanga Mine and their potential uses

\begin{tabular}{|c|c|c|c|c|}
\hline Mine waste & Description & $\begin{array}{l}\text { Generated } \\
\text { from }\end{array}$ & Disposal site & $\begin{array}{l}\text { Potential use if } \\
\text { any. }\end{array}$ \\
\hline Tailings & $\begin{array}{l}\text { Materials left over after the } \\
\text { process of separating the valuable } \\
\text { fraction from the uneconomic } \\
\text { fraction af an } \\
\text { ore(low-grade/gangue) }\end{array}$ & $\begin{array}{l}\text { Concentration of } \\
\text { crushed and } \\
\text { ground ore }\end{array}$ & Tailings dump & $\begin{array}{l}\text { Can be recycled and } \\
\text { used to make } \\
\text { construction } \\
\text { materials }\end{array}$ \\
\hline Overburden & $\begin{array}{l}\text { Material that lies above an ore } \\
\text { body }\end{array}$ & $\begin{array}{l}\text { Development of } \\
\text { surface mining }\end{array}$ & $\begin{array}{l}\text { Overburden } \\
\text { stockpiles }\end{array}$ & $\begin{array}{l}\text { Backfilling of } \\
\text { closed mine sites } \\
\text { Construction of } \\
\text { Tailings dams. }\end{array}$ \\
\hline Waste rock & $\begin{array}{l}\text { Valueless (to the mine) rock that } \\
\text { must be removed to gain access to } \\
\text { the ore }\end{array}$ & $\begin{array}{l}\text { Development of } \\
\text { underground } \\
\text { mine }\end{array}$ & $\begin{array}{l}\text { Waste rock } \\
\text { stockpiles }\end{array}$ & $\begin{array}{l}\text { Backfilling of } \\
\text { mined out stopes, } \\
\text { Construction of } \\
\text { Tailings dams. }\end{array}$ \\
\hline $\begin{array}{l}\text { Mine waste } \\
\text { water }\end{array}$ & $\begin{array}{l}\text { Water adversely affected by } \\
\text { mining processes, potential } \\
\text { pollutants include; oils, chemicals } \\
\text { (sulphuric acid), cobalt, and } \\
\text { copper. }\end{array}$ & $\begin{array}{l}\text { Seepage to } \\
\text { excavated area }\end{array}$ & $\begin{array}{l}\text { Pumped to } \\
\text { Muntimpa and } \\
\text { Nchanga } \\
\text { stream }\end{array}$ & $\begin{array}{l}\text { Treated } \\
\text { recycled } \\
\text { water is used for } \\
\text { cooling, drinking } \\
\text { and } \\
\text { suppression }\end{array}$ \\
\hline
\end{tabular}

\subsection{Social Contributions of KCM Mining Operations on Nchanga North Residents}

The social impacts of the mining activities in Nchanga North Township are both positive and negative and relate to social indicators such as health, employment, population increase, migration, economic, and infrastructural development. There is general acceptance in the community on the impacts of mining activities in the community in any of these ways. Respondents indicated that they have been affected by major social and structural changes in the community since mining began.

\subsection{Health Implications of Mining Activities on Residents}

Respondents were asked whether members of their households suffered from respiratory diseases. Majority of the respondents (74\%) indicated that residents frequently complained of colds and flu, while $26 \%$ of the respondents said it was rare that members of their households suffer from any respiratory diseases. According to a key informant interviewed at Chingola District Health Board (CDHB), cases of respiratory diseases among Nchanga North residents have reduced in the recent years from $86 \%$ in 2006 to $32 \%$ in 2016 due to improved waste disposal methods and improved mining operations.

KCM owns and operates two hospitals, namely; Nchanga North and Nchanga South Hospitals, as well as clinics in Chingola. The health facilities provide free health care to its 
employees and their dependants. However, health facilities are also accessible to non-employees on cost recovery basis (Dymond et al, 2007). KCM has a Roll Back Malaria Control Programme that aims at reducing malaria incidences in Chingola (Dymond et al, 2007). The Company funded spraying of more than 36500 houses within a $10 \mathrm{~km}$ radius of Chingola in 2006. As a result, incidences of reported malaria cases have reduced by over 60 per cent.

\subsection{Local Employment and Livelihoods}

The presence of Nchanga Mine in Nchanga North Township has created and generated some business and economic opportunities for the people of Nchanga North Township. Results from observations revealed that some people were engaged in business ventures such as selling of phone card and credits, operating mini-restaurants, selling food and water on the streets as well as general merchandise as stated by respondents. In a study by Kitula (2004), it was observed that while some local people who were employed in mining obtained direct income as mining wages, the non-miners and many people in the community increased their income through different socioeconomic activities, including sales from food crops and menial business activities. Hence the thriving of economic activities in Nchanga was dependent on a thriving mining sector.

Regarding employment, KCM is the second largest employer in Zambia after the government. It has approximately 16,000 employees, with 10,000 directly and 6,000 employees employed through sub-contracted firms(KCM, 2017). However, according to the key informant from $\mathrm{KCM}$, it was suggested that there are as many as 9,575 contract workers. Therefore, KCM is the key employer in Chingola employing about $75 \%$ of the total workforce in the district and providing a much needed source of family income in an area.

As part of community contribution KCM owns and operates one school in Chingola called Chingola Trust School. The school provides basic primary school education to over 1,000 (Dymond, 2007) children of both mine employees and non- mine employees. However, non-mine employees pay for school fees for their children and the prices are fairly high for an average Chingola resident.

\subsection{Houses That Shake During Blasting and Houses with Cracks}

Through interviews and observations, it was found that majority (72\%) felt their houses shake during blasting while $28 \%$ of respondents did not feel their houses shaking during blasting. The other $40 \%$ of respondents said the walls of their houses have cracks (Figure 2a-b) while $60 \%$ said no cracks have occurred on the walls of their houses. 
Figure 2. Cracked walls on two Nchanga North Township houses as of April 2017

\subsection{Noise Pollution in Nchanga North Township}

Noise pollution in the community is mainly from blasting at the mining site. The blasting noise is loud enough to shake building foundations houses located near the mine. It was also said to be responsible for cracks in buildings in Nchanga North Township. According to KCM (2015), this noise is mostly produced at Nchanga Open pit (NOP) but is audible to over $53 \%$ of the residents in Nchanga. The people who complained of hearing noise from the mine were those whose houses were in close proximity to the mine. Since mining operations are carried out on a 24 hours 7 days a week basis, this noise was a source of adverse impact on residents as it disturbed people's rest thereby posing risk to insomnia. It can also be detrimental to human health as it causes damage of the cells of corti of the inner ear and hence may cause noise deafness after a long period of exposure to the noise. The noise shock could also be dangerous for hypertensive and cardiac patients. Figure 3 below shows residents' perceptions on the source of noise in Nchanga North Township. 


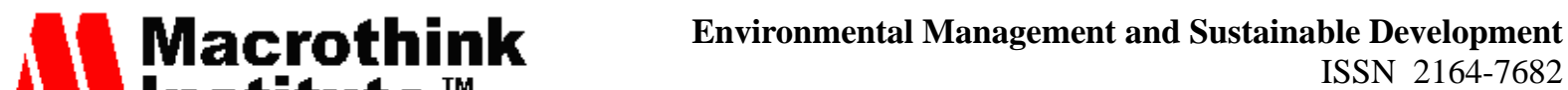 2019, Vol. 8, No. 4}

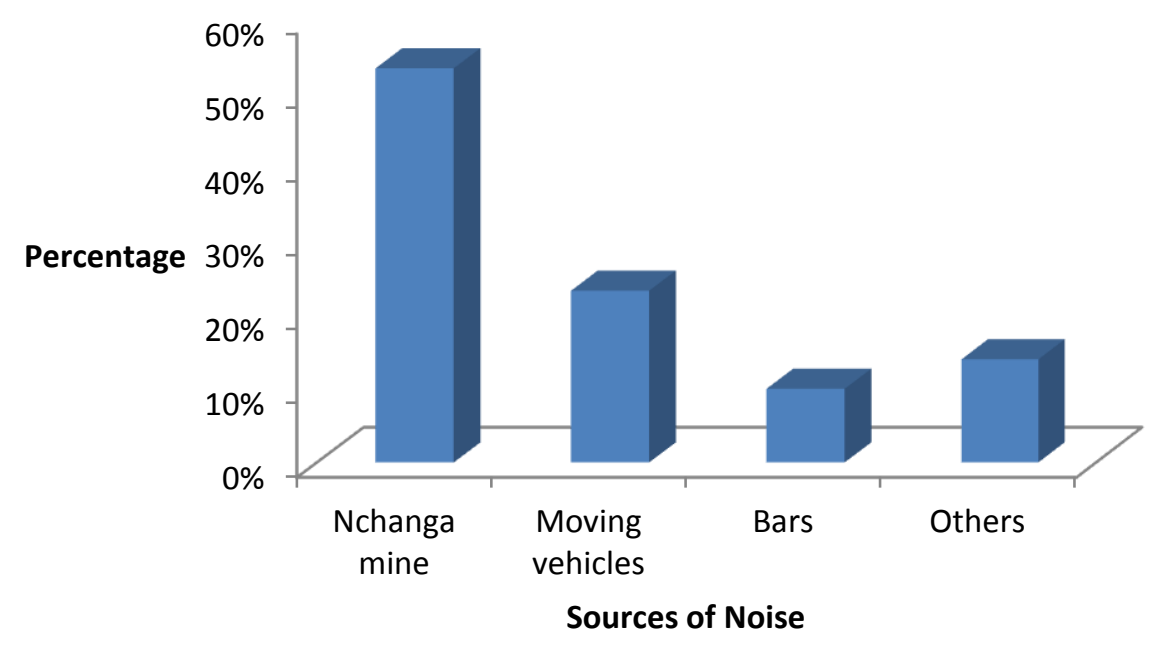

Figure 3. Residents' Perceptions on Sources of Noise in Nchanga North Township as of April 2017

\subsection{Environmental Impacts of KCM's Mining Operations on Nchanga North Residents}

\subsubsection{Air Contamination Resulting from Dust}

Mining activities introduce lots of dust into the ambient air primarily due to mobility of mining equipment on gravel roads around the mining area (KCM 2014). Although Zambia Environmental Management Agency (ZEMA) regulations stipulate that dust around a mining area should be controlled through deliberate actions such as watering the drive ways, this requirement was minimised by the developers and contributed to the dust pollution. Clean air is very important because its lack thereof can have very serious consequences on the health of the people affected. Besides mining activities involving blasting, air pollution in Nchanga North Township mainly comes from the dusty un-tarred roads that are continually used by heavy-duty vehicles belonging to Nchanga Mine for transporting machines and other equipment to the mine sites. The most affected were residents nearest to the mine because the concentrations of dust were high at the source and reduced with distance. An observation on the leaves of the vegetation displayed the same pattern with the vegetation nearest to the Mine having more dust than vegetation furthest from the Mine.

It was difficult to visibly see chemical gases, fumes and smoke from the mining site. However, during the blasting of the earth, dust was observed in ambient air environment for a while before it settled. Chemicals that are used in the blasting process are also released into the atmosphere. A key informant from the health department linked this high concentration of dust in the area to the increased respiratory ailments such as flu and cold (catarrh) recorded in the area. This finding agrees with what was observed by Akabzaa and Darimani (2001: 56) who stated that "all fine dust at a high level of exposure has the potential to cause respiratory 


\section{Macrothink}

diseases and disorders and can worsen the condition of people with asthma and anthracosis". Figure 4 below shows residents' perceptions on the levels of dust in Nchanga North Township.

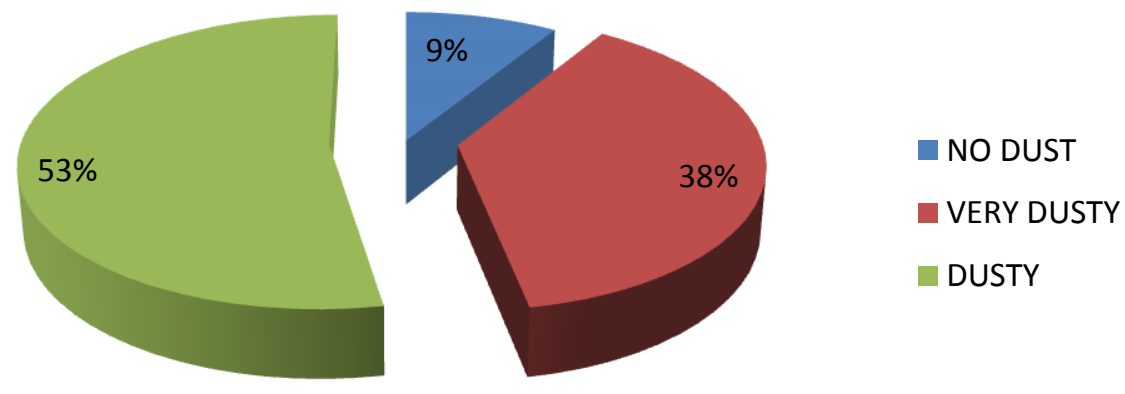

Figure 4. Residents' Perceptions on Levels of Dust in Nchanga North Township as of April 2017

\subsection{Sources of Dust}

Table 2. Residents' Perceptions on sources of dust in Nchanga North Township as of April 2017

\begin{tabular}{|l|c|c|}
\hline Sources of dust & Responses & Percentage \\
\hline Nchanga mine & 38 & 63.3 \\
\hline Natural wind & 14 & 23.3 \\
\hline Construction works and Traffic & 8 & 13.4 \\
\hline TOTAL & $\mathbf{6 0}$ & $\mathbf{1 0 0}$ \\
\hline
\end{tabular}

\subsection{Impacts of Mining on Land and Soils}

Soil is a vital resource for the people of Nchanga North Township as farming was a major livelihood for the community besides mining. However, mining in any form or scale appropriates the land and can cause serious devastation and degradation of it, Nchanga North Township is no exception. The impacts of mining activities by Nchanga Mine especially through excavation in Nchanga has affected the land and degraded as vast areas have been eroded and replaced with built environment. Some of the original settlers in the area have been displaced. The observed land degradation due to excavation of huge pits at the mine in search of copper ore and cobalt ore is also a problem because after the ore stocks are depleted, the land will not be used for any agricultural production, forestry or human settlement due to 
the pits, and exposed bare rock surfaces. The observed scenario was in line with what (Anon 1985) stated that open pit mining can quickly transform a scenic area of breath-taking beauty into an ugly wasteland.

Tests for soil $\mathrm{pH}$ were carried out on eight composite soil samples from Nchanga North Township.Measurements of soil $\mathrm{pH}$ were carried out in order to give an indication of the presence of $\mathrm{pH}$ raising or decreasing contaminants in the soil (Table 3 ). The soil $\mathrm{pH}$ was within the normal range. However, most respondents said that soil around their houses was not fertile and could not support the growth of any crops in their backyards without the addition of chemical fertilizers. Almost all households interviewed had gardens in their backyards and only grew vegetables, but did not practice nutrient replenishing crop husbandry practices such as crop rotation, mulching or use of organic manure. This could have also contributed to the reduced fertility observed in the soil.

Table 3. The $\mathrm{pH}$ values for soil samples from Nchanga North Township as of April 2017

\begin{tabular}{|c|c|c|}
\hline Sub-Sample & pH Value & Normal soil $p H$ \\
\hline 1 & 8.14 & \multirow{8}{*}{6.25} \\
\hline 2 & 7.03 & \\
\hline 3 & 5.07 & \\
\hline 4 & 6.78 & \\
\hline 5 & 6.13 & \\
\hline 6 & 5.04 & \\
\hline 7 & 6.12 & \\
\hline 8 & 5.32 & \\
\hline
\end{tabular}

There was no significant difference between the $\mathrm{pH}$ values measured at the eight soil samples in Nchanga North Township (mean $=6.20$; range $=5.07-8.14$ ) and the expected normal soil $\mathrm{pH}($ mean $=6.25 ; \mathrm{t}=-0.121 ; \mathrm{p}=0.907)$ at $\mathrm{p}=0.05$. This implies that there was no $\mathrm{pH}$ raising or decreasing contaminants in the soil.

\subsection{Water Sanity and $p H$}

The average water $\mathrm{pH}$ was found to be within the parameters recommended by W.H.O guidelines for drinking water which is 6.5 to 8.5 . This implies that there was no $\mathrm{pH}$ raising or decreasing contaminants in the Kafue River at the point of sample collection. Management at Nchanga Mine said that waste water from Tailings Leach Plant is treated and neutralized with lime to control $\mathrm{pH}$. In this regard, the $\mathrm{pH}$ of water is adequately maintained at levels suitable for human consumption. However, the researcher was not permitted to collect the water from the point of discharge into the Kafue River and had to collect the sample some 10m away from the point of discharge and this could have had an effect on the results.

According to KCM (2015), water pumped to the underground was and is still a potential concern due to the concentration of dissolved suspended solids that result from carry overs from sediments with run-off from pit slopes. The water that is pumped to the households is treated by Mulonga Water and Sewerage Company, despite the majority of residents $(78.3 \%)$ claiming they were able to see particles in their drinking water. Observations from the 


\section{Macrothink}

researcher confirmed the suspended solid particles in water from taps. This could highlight a series of inefficiency in water treatment by both KCM and Mulonga Water and Sewerage Company. The suspended solids in domestic water supply had the potential to cause health implications among the residents.

\subsection{Presence of Suspended Solids in Drinking Water}

The researcher observed some suspended particles in the drinking water consumed by Nchanga North residents.

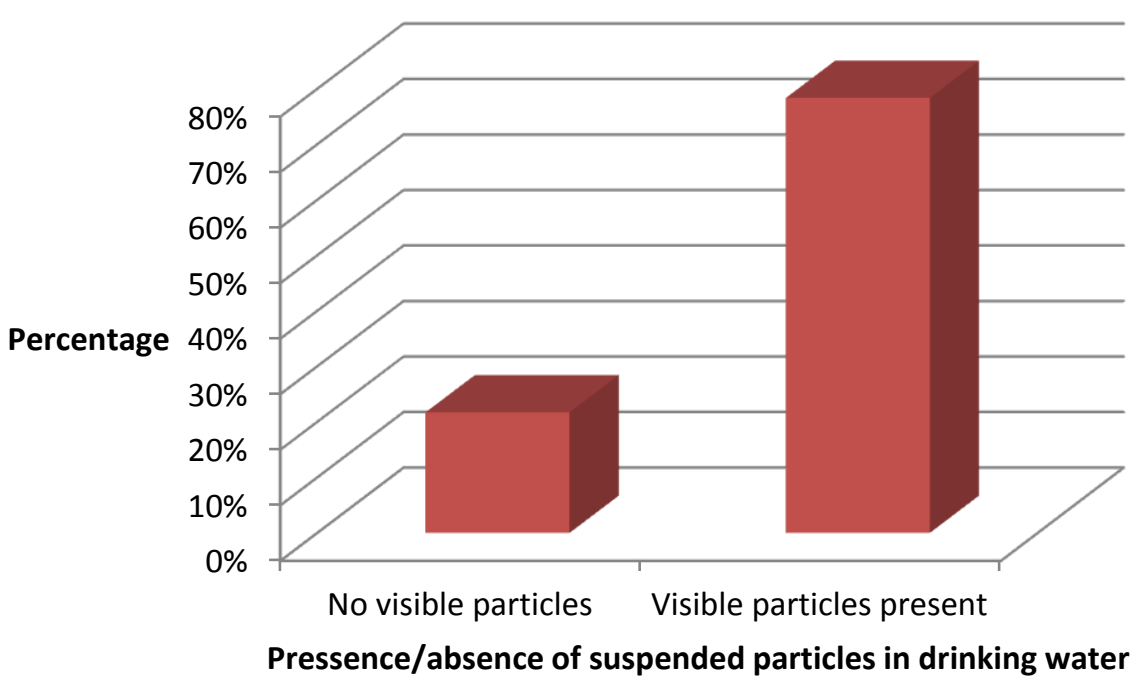

Figure 5. Residents' perceptions on the presence of suspended particles in drinking water of Nchanga North Township

Most respondents (65\%) said that the drinking water had an unusual taste and $35 \%$ said that the drinking water had a normal taste.

\section{Methods of Mine Waste Disposal}

\subsection{Tailings Management}

Tailings are the major solid wastes produced in the process of mineral beneficiation. In order to extract usable minerals, ore is crushed and milled to appropriate size, then, the usable minerals are separated from unusable minerals via different beneficiating methods. With the development and utilization of mineral resources, the production and disposal of tailings has become the important factor in the sustainable development of mining industry and endangering mining and surrounding area ecological environment. The tailings should be disposed in time, otherwise, they would occupy land, pollute environment and even influence life of people. The disposal methods of tailings at Nchanga mine is pumping tailing slurry to tailings dams or transmit the dry tailing to tailings storage facility (TSF). Tailings are sometimes used for improving the soil fertility, filling depressions and separating out coarser size for fine aggregate of concrete and building sand usage. 


\subsection{Reclamation of Waste Rock and Waste Water}

Comprehensive utilization of solid waste resources is an important disposal method of solid waste from mines. Waste rock results from stripping in an open-pit or excavation of an underground mine. Usually, according to the difference utilities of waste rock, it is used directly or dressed to various sizes for construction of roads, dams, tailings dams/tailings storage facilities and to backfill the mined out area, subsidence area and other area needed to be filled.

According to a key informant from Nchanga Mine, Nchanga Mine management recognized that backfilling of the mined area is not only significant to the environmental restoration and improving the mining condition, but also a good idea of disposal method on solid waste from mines. Backfilling the mined out area could decrease the amount of land usage and reduce the impacts on environment and eco-environment. With the development of backfilling technology, more and more solid waste from industry, such as tailings, waste rock and smelter could be used as backfill materials.

Processed wastewater is generated by wash down facilities, copper and cobalt conveyor cleaning, oil storage, diesel filling areas, and on-site mineral processing facility (Table 3). The likely contaminants are oil, copper, cobalt, and other solid materials. The quantity and characteristics of wastewater are highly variable. According to the key informant, this water meets the local and international guidelines before disposal to the environment. This water is usually recycled and treated for various uses including; dust suppression within the mine, domestic use and reuse in the mine processes.

\subsection{Mitigation Measures of the Environmental and Social Impacts of Mining by KCM}

According to management, one of the mitigation measures aimed at improving environmental quality include the provision of impervious surfacing and containment of hazardous material storage and handling such as the fuel stations and workshops. This is intended to reduce soil contamination by fuel, oil and hazardous materials such as highly concentrated acids. Oil traps have been installed on drainages in areas like fuel stations and workshops; this is to prevent contamination of underground water resources. The company has also constructed erosion and storm water management infrastructure. Management at Nchanga Mine has developed an emergency response plan, aimed at cushioning the environmental and social impacts of mining activities on the surrounding environment of Nchanga North Township.

$\mathrm{KCM}$ has been conducting its corporate social responsibility as a way of mitigating some environmental and social impacts on the residents of Nchanga North Township. For example, since 2005, KCM has invested over US\$ 150 million in corporate social responsibility (CSR) relating to education, health, sustainable livelihoods, environment and biodiversity projects (KCM 2015). The company has over time been implementing various community programs and projects such as the malaria roll back, HIV/AIDs, hospitals, schools and the provision of business to the local communities.

\section{Conclusion}


According to the residents' perceptions, mining operations at Nchanga Mine have had negative environmental and social impacts on residents of Nchanga North Township. The dust released into the air lowers air quality thereby increasing the prevalence of respiratory diseases such as coughs among residents especially those residing in Nchanga North Township because their proximity to the mine. Furthermore, there is a perceived reduction in water quality because of suspended particles resulting from carry overs of sediments when runoff from pit slopes are discharged in water consumed by residents. Mining activities at Nchanga Mine also cause noise pollution which is a public nuisance as it disturbs Nchanga North Township residents.

The lowered environmental quality could be a health hazard to residents. Measures to address these negative environmental and social impacts by $\mathrm{KCM}$ were found inadequatedue to a lack of a deliberate policy in use aimed at improving the environment around residents' households in Nchanga North Township. The important issues on disposal of solid waste from metal mines are to choose the right varieties for the comprehensive utilization of mine waste and to control contamination from waste rock and tailings. The comprehensive utilization of solid wastes from mines is the necessary choice of mining industry, and it has the potential to result in economic and social benefits especially in environmental protection. Sustainable management of solid waste from mines should encourage not just reducing the discharge of solid waste but recycling the discharged wastes through the comprehensive utilization of mining waste. This will turn the mining waste into useful raw materials.

\section{References}

Akabzaa, T. (2009). Mining in Ghana: Implications for National Economic Development and Poverty Reduction. [Online] Available:

http://www.idrc.ca/en/ev-141150-201-1-DO_TOPIC.html

Anon, M. (1985). Wastes from the Extraction and Beneficiation of Metallic Ores, Phosphate Rock, Asbestos, Overburden from Uranium Mining, and Oil Shale, EPA, Report to Congress: p. ES-17.

Anon, M. (1998).Base metal and iron ore mining, Pollution Prevention and Abatement Handbook, World Bank, pp 1. [Online] Available:

http://www.ifc.org/ifcext/enviro.nsf/AttachmentsByTitle/gui_mining_WB/\$FILE/mining_PP AH.pdf

Anon, M. (2006). Dirty Metal, Mining Communities and Environment. Earthworks, Oxfam America, Washington, pp. 4.

Braun, V., \& Clarke, V. (2006). Using thematic analysis in psychology. Qualitative Research in Psychology, 3(2). 77-101. https://doi.org/10.1191/1478088706qp063oa

Bryman, A. (2008). Social Research Methods, (3rd edition), Oxford University Press

Central Statistics Office, Republic of Zambian, (2012). Census of Population and Housing, GRZ Printers, Lusaka, Zambia 
Chansa, M. (2006). KCM pollutes Kafue River. Times of Zambia, Wednesday, November 8, 3.

Das, R., \& Choudhury, I. (2013). Waste Management in Mining Industry. Department of Mining Engineering, Godavari Institute of Engineering and Technology, Rajahmundry, A. P., India.

Dymond, A., Lambrechts, K., \& Chase, S. (2007). Undermining Development? Copper Mining in Zambia. ACTSA London

Environmental Council of Zambia (ECZ), (2001). State of the Environment in Zambia 2000, ECZ, Lusaka, Zambia

Feeney, P. (2001).The limitations of Corporate Social Responsibility on Zambia's Copperbelt: K.C.M. Environmental Management Plan, Oxfam, Oxford

Kitula, A. G. N. (2004). The Environmental and Socio-economic Impacts of Mining on Local livelihoods in Tanzania.

Konkola Copper Mine (KCM), (2015). Annual Report and Accounts. [Online] Available: http://sustainabledevelopment.vedantaresources.com

Konkola Copper Mines (KCM), (2013). Annual Report and Accounts. [Online] Available: http://sustainabledevelopment.vedantaresources.com

Konkola Copper Mines (KCM), (2014). Annual Report and Accounts. [Online] Available: http://sustainabledevelopment.vedantaresources.com

Konkola Copper Mines (KCM), (2017). Annual Report and Accounts. [Online] Available: http://sustainabledevelopment.vedantaresources.com

Mwitwa, C., \& Kabemba, C. (2007). Copper boom in Zambia: Boom for whom?. Resource Insight, 3.

Naicker, K., Cukrowska, E., \& McCarthy, T. S. (2003). Acid mine drainage from gold mining activities in Johannesburg, South Africa and environs. Environmental Pollution, 122, 29-40. https://doi.org/10.1016/S0269-7491(02)00281-6

Ngulube, R., Nakena, K. K., Nyirenda, K., \& Siakamba, A. (2016). A Review of Nchanga Tailings Dam Operations and Seasonal Assessment of Its Effluent Quality. American Journal of Environmental Protection, 5(4), 90-96. https://doi.org/10.11648/j.ajep.20160504.13

Pulles, W., Banister, S., \& Van Biljon, M. (2005). The development of appropriate procedures towards and after closure of underground gold mines from a water management perspective. Report No. 1 215/1/05. Water Research Commission, Pretoria.

Rhett, B. A. (2006). Environmental impact of mining in the rainforest. Mongabay.com / A Place Out of Time: Tropical Rainforests and the Perils They Face. [Online] Available: http://rainforests.mongabay.com/0808.htm

Von der Heyden, J. C., \& New, G. M. (2004). Sediment Chemistry: A History to Mine Contaminant Remediation and Assessment of Processes and Pollution Potential. Journal of 


\section{Macrothink}

Environmental Management and Sustainable Development

ISSN 2164-7682

2019, Vol. 8, No. 4

Geochemical Exploration, 82, 35-57. https://doi.org/10.1016/j.gexplo.2003.11.001

\section{Copyright Disclaimer}

Copyright for this article is retained by the author(s), with first publication rights granted to the journal.

This is an open-access article distributed under the terms and conditions of the Creative Commons Attribution license (http://creativecommons.org/licenses/by/3.0/). 